\title{
21-Day Lockdown in India Dramatically Reduced Air Pollution Indices in Lucknow and New Delhi, India
}

\author{
Sudhakar Srivastava ${ }^{1} \cdot$ Amit Kumar $^{2}$ (D) $\cdot$ Kuldeep Bauddh $^{3} \cdot$ Alok Sagar Gautam $^{4} \cdot$ Sanjeev Kumar ${ }^{4}$
}

Received: 30 April 2020 / Accepted: 26 May 2020 / Published online: 3 June 2020

(c) Springer Science+Business Media, LLC, part of Springer Nature 2020

\begin{abstract}
In December 2019, the outbreak of viral disease labeled as Novel Coronavirus started in Wuhan, China, which later came to be known as Covid-19. The disease has spread in almost every part of the world and has been declared a global pandemic in March 2020 by World Health Organization (WHO). The corona virus outbreak has emerged as one of the deadliest pandemics of all time in human history. The ongoing pandemic of COVID-19 has forced several countries of the world to observe complete lockdown forcing people to live in their homes. India also faced the phase of total lockdown for 21 days (in first phase) to avoid the spread of coronavirus to the maximum possible extent. This lockdown impacted the pollution levels of environment and improved air and water quality in the short span owing to very less human activities. The present work scientifically analyzed the available data for primary air pollutants $\left(\mathrm{PM}_{2.5}, \mathrm{NO}_{2}, \mathrm{SO}_{2}\right.$ and $\left.\mathrm{CO}\right)$ from two major Indian cities, Lucknow and New Delhi. The analysis was based on air quality data for before lockdown and after lockdown (first phase of 21 days) periods of 21 days each. The results showed significant decline in the studied air pollution indices and demonstrated improvement of air quality in both the cities. The major impact was seen in the levels of $\mathrm{PM}_{2.5}, \mathrm{NO}_{2}$ and $\mathrm{CO}$. The levels of $\mathrm{SO}_{2}$ showed less significant decline during the lockdown period. The results are presented with future perspectives to mitigate air pollution in near future by adopting the short and periodical lockdown as a tool.
\end{abstract}

Keywords Air pollution $\cdot$ Air quality $\cdot$ COVID-19 $\cdot$ Lockdown $\cdot$ PM2.5

Since the first case of coronavirus, named as COVID-19, in Wuhan, China (Zhu et al. 2020), COVID-19 became a pandemic in a short span of time. As on May 15, 2020 (2.00 am; Indian Standard Time; UTC + 05:30), total 4,258,666 coronavirus cases and 294,190 deaths of coronavirus patients

Electronic supplementary material The online version of this article (https://doi.org/10.1007/s00128-020-02895-w) contains supplementary material, which is available to authorized users.

Amit Kumar

amit_gene@yahoo.com

1 Plant Stress Biology Laboratory, Institute of Environment and Sustainable Development, Banaras Hindu University, Varanasi 221005, India

2 Department of Botany, University of Lucknow, Lucknow 226007, India

3 Department of Environmental Sciences, Central University of Jharkhand, Ranchi 835205, India

4 Department of Physics, Hemvati Nandan Bahuguna Garhwal University (A Central University), Srinagar, Garhwal, Uttarakhand, India have been reported from 216 countries of the world (WHO 2020). India is hugely populated country with a population of 1.38 billion as of March, 2020, which is second most in the world (Ministry of Statistics and Programme Implementation 2020). The problem of huge population is worsened by the fact this population lives in a country, which is 7th largest in the world (Shabudeen 2011) entailing that the density of people residing in per square $\mathrm{km}$ area is high. Indian cities are hugely populated with New Delhi ranking 2nd most populated city in the world (World Urbanization Prospects 2020). Further, Indian healthcare system is also poor and lacks sophisticated facilities and specialized doctors especially in small towns and villages (Ramani and Mavalankar 2006; Banerjee et al. 2008). India, therefore, lies at huge risk from current pandemic of COVID-19. As a safety precautionary measure, Prime Minister of India, Shri Narendra Modi, took an extremely bold decision and declared 21 days complete lockdown in India from midnight of 24 March (25 March, 2020-14 April, 2020). Earlier, "Janta Curfew" (a sort of complete lockdown; maintained by the public for the public; Fig S1, S2) was performed on 22nd March, 2020 in 
India. Such a lockdown was enforced in China in Wuhan, China on 23rd January, 2020 and was lifted on 8th April, 2020 (total 76 days). This lockdown helped China to reduce the number of infections to close to zero.

During past 3 months, since coronavirus outbreak began, numerous studies have examined COVID-19 infection. A lot of research on the nature of its spread, the mechanisms of its transfer from human to human, the genome of COVID19 , the mechanisms of its infection in human cells and its effects on various tissues has been published (Chen et al. 2020; Guo et al. 2019; Baig et al. 2020; Gu et al. 2020; Driggin et al. 2020). It is apparent that the lockdown and consequent reduced mobility of people and industrial and almost all other human operations would have also impacted air pollution. In fact, several studies have been published during the last few weeks for Europe, China, Latin America (He et al. 2020; Ma et al. 2020; Wang et al. 2020; Nakada and Urban 2020). Indian lockdown is first such event locking almost 1.38 billion people in their homes and closing down almost all activities in such a large country. In India also, a few studies have shown the positive impact of the lockdown on air and water pollution (Sharma et al. 2020; Mahato et al. 2020; Gautam 2020).This article scientifically examines the impact of lockdown on air pollution indices in two major cities of India, New Delhi and Lucknow. New Delhi is the capital of India with an area of $1448 \mathrm{~km}^{2}$ and total population of 21.8 million. Apart from this, seven other cities around New Delhi namely Noida, Ghaziabad, Karnal, Faridabad, Greater Noida, Meerut and Gurgaon make a huge cluster and contribute to human and industrial activities. Lucknow is the capital of Uttar Pradesh with an area of $349 \mathrm{~km}^{2}$ and total population of 2.82 million. Both the cities are known to experience severe pollution load days during early winter for the past 2-3 years. During 05 November, 2019, the air quality index (AQI) in New Delhi and Lucknow ranged from 283-500 to 267-486, respectively, which was poor (Unhealthy) to severe as per National Air Quality Index (NAQI 2014) (Table S2). The present study analyzed air pollution indices for before and after lockdown periods (21 days each) for the two cities.

\section{Materials and Methods}

Our present study used a comprehensive air quality data in two cities of India, Lucknow and New Delhi. Air quality data were collected from fourteen sites viz. Central School, Gomti Nagar, Lalbagh and Talkatora of Lucknow city and Anand Vihar, Bawana, CRRI Mathura Road, Dwarka-Sector 8, IGI Airport (T3), DU North Campus, Pusa, Rohini, Vivek Vihar and Wazirpur of Delhi city (Fig. 1). The main concern of the paper was to analyze the trend of concentration of $\mathrm{PM}_{2.5}, \mathrm{SO}_{2}, \mathrm{NO}_{2}$ and $\mathrm{CO}$ at different sites for before
(01/02/2020 to 21/02/2020) and after lock down (25/03/2020 to 14/04/2020) periods of 21 days (first phase of lockdown in India). All the data were collected form National Air Quality Index, Central Pollution Control Board of India, website (CPCB 2020).

The air quality index (AQI) is defined as ratios of the measured concentration of the atmospheric pollutants to their standard prescribe values (Deep et al. 2019; Joshi and Mahadev 2011). Mathematically, the AQI can be evaluated by using following equation for primary pollutants, Eq. 1:

$A Q I=\frac{1}{3}\left[\left(\frac{P M_{2.5}}{s P M_{2.5}}\right)+\left(\frac{S O_{2}}{s S O_{2}}\right)+\left(\frac{N O_{2}}{s N O_{2}}\right)\right] \times 100$

The $\mathrm{sPM}_{2.5}, \mathrm{sSO}_{2}, \mathrm{sNO}_{2}$ are ambient air quality standards as given by the Central Pollution Control Board of India (CPCB) and $\mathrm{PM}_{2.5}, \mathrm{SO}_{2}$ and $\mathrm{NO}_{2}$ represent the actual observational values of pollutants (Punith and Nagarajappa 2017). The AQI was calculated by using mass concentration of these three primary pollutants $\left(\mathrm{PM}_{2.5}, \mathrm{SO}_{2}\right.$ and $\left.\mathrm{NO}_{2}\right)$ for all specified locations. The high AQI values represent a higher level of atmospheric pollutants at the monitoring site. According to Deep et al. (2019); Guttikunda et al. (2010) and NAQI (2014), the AQI scale can be divided into six different categories as per the range and associated health impacts (Table S2).

To understand the influence of long-range transportation of atmospheric pollutants at both monitoring zones, the air mass back trajectory analysis was also performed. The air mass back trajectory was extracted from National Oceanic and Atmospheric Administration (NOAA) Air Resources Laboratory (ARL) Hybrid Single-Particle Lagrangian Integrated Trajectory (HYSPLIT) model (Stein et al. 2015). The 5 days air mass back trajectories were calculated for local time 12:00 at the elevation of $800 \mathrm{~m}$ from mean sea levels (He et al. 2003; Rozwadowska et al. 2010) for both cities.

\section{Results and Discussion}

The data of air quality parameters i.e. $\mathrm{PM}_{2.5}, \mathrm{NO}_{2}, \mathrm{SO}_{2}$ and $\mathrm{CO}$ were taken for four locations of Lucknow and ten locations of New Delhi for before lockdown (01/02/2020 to $21 / 02 / 2020)$ and after lockdown $(25 / 03 / 2020$ to $14 / 04 / 2020)$ periods (Tables S1A, B). The level of $\mathrm{PM}_{2.5}$ varied from avg 48-369 $\mu \mathrm{g} / \mathrm{m}^{3}$ in four locations of Lucknow before lockdown. On 25th March, 2020, $\mathrm{PM}_{2.5}$ level was the lowest $105 \mu \mathrm{g} / \mathrm{m}^{3}$ at Gomti Nagar and highest $217 \mu \mathrm{g} / \mathrm{m}^{3}$ at Talkatora. On 30th March 2020, $\mathrm{PM}_{2.5}$ levels declined to 58 and $76 \mu \mathrm{g} / \mathrm{m}^{3}$, respectively in these areas while to 54 and $222 \mu \mathrm{g} /$ $\mathrm{m}^{3}$, respectively on 14th April, 2020 (Fig. 2a). In New Delhi, the $\mathrm{PM}_{2.5}$ level ranged from 85 to $456 \mu \mathrm{g} / \mathrm{m}^{3}$ during before lockdown period in different locations. On 25th March, 2020 


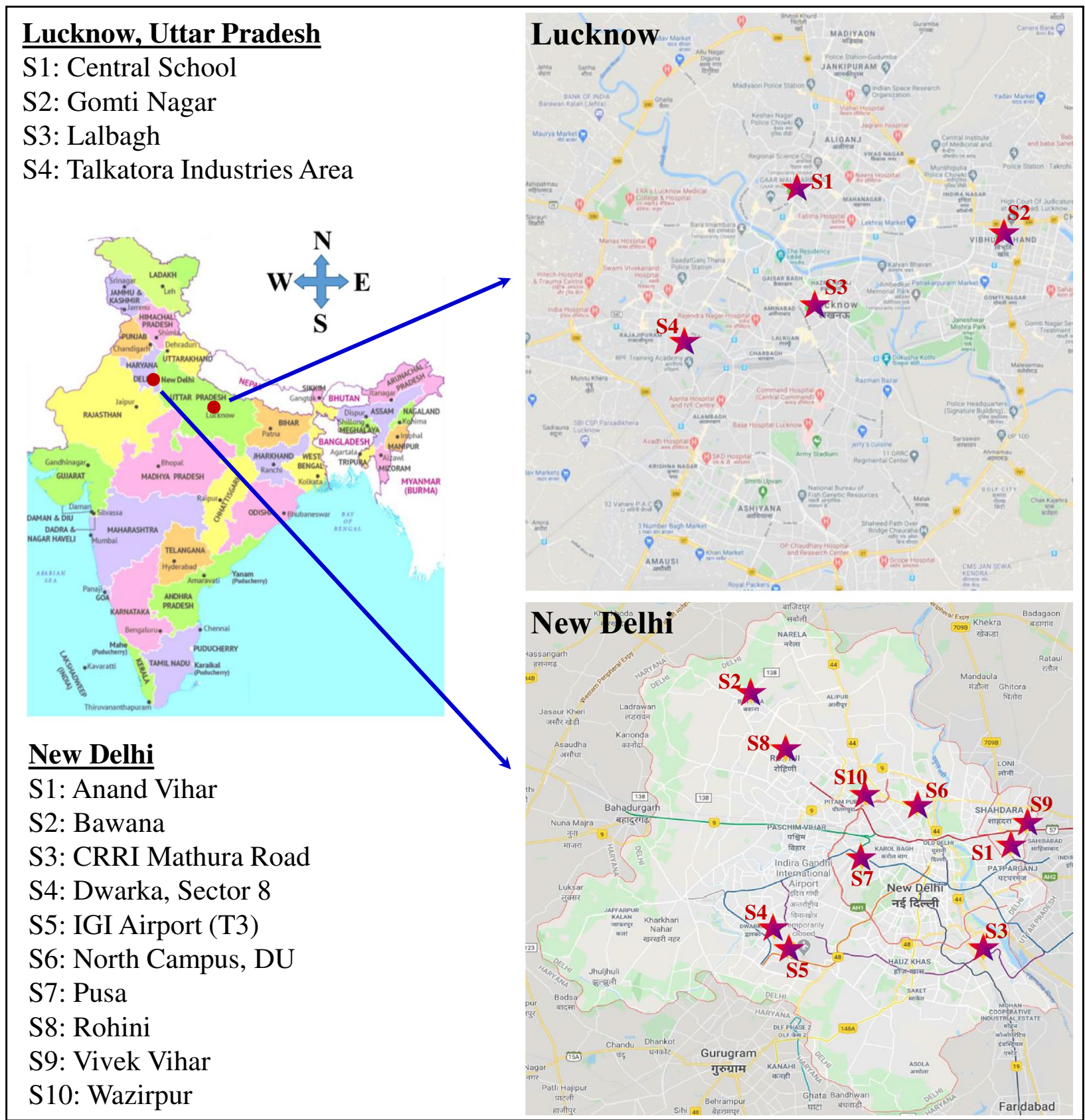

Fig. 1 Location of the study area in Lucknow (UP) and New Delhi, India

the range of $\mathrm{PM}_{2.5}$ was 76 to $164 \mu \mathrm{g} / \mathrm{m}^{3}$ and on 14th April, 2020 , it was 47 to $204 \mu \mathrm{g} / \mathrm{m}^{3}$ (Fig. 3a).

The range of $\mathrm{NO}_{2}$ before and after lockdown period in Lucknow was $22-158 \mu \mathrm{g} / \mathrm{m}^{3}$ and $3-59 \mu \mathrm{g} / \mathrm{m}^{3}$, respectively denoting a significant decline (Fig. 2b). In New Delhi also, before and after lockdown levels of $\mathrm{NO}_{2}$ were significantly different. Before lockdown, $\mathrm{NO}_{2}$ ranged from 4 to $158 \mu \mathrm{g} /$ $\mathrm{m}^{3}$ while after lockdown, it ranged from 9 to $112 \mu \mathrm{g} / \mathrm{m}^{3}$. The low value of $4 \mu \mathrm{g} / \mathrm{m}^{3}$ in New Delhi before lockdown was from Indira Gandhi International Airport Terminal-3
(Fig. 3b). Thus, even before lockdown, some highly maintained and clean areas had low pollution levels. The levels of $\mathrm{SO}_{2}$, however, did not show much change before and after lockdown in both Lucknow and New Delhi (Figs. 2c, $3 c)$. The level of CO showed decline from $20-199 \mu \mathrm{g} / \mathrm{m}^{3}$ to $3-55 \mu \mathrm{g} / \mathrm{m}^{3}$ in Lucknow while from $15-150 \mu \mathrm{g} / \mathrm{m}^{3}$ to $5-98 \mu \mathrm{g} / \mathrm{m}^{3}$ in New Delhi (Figs. 2d, 3d).

The average and median (Fig S3) values of all these four parameters were also calculated for both the cities for before and after lockdown period (21 days). The minimum 

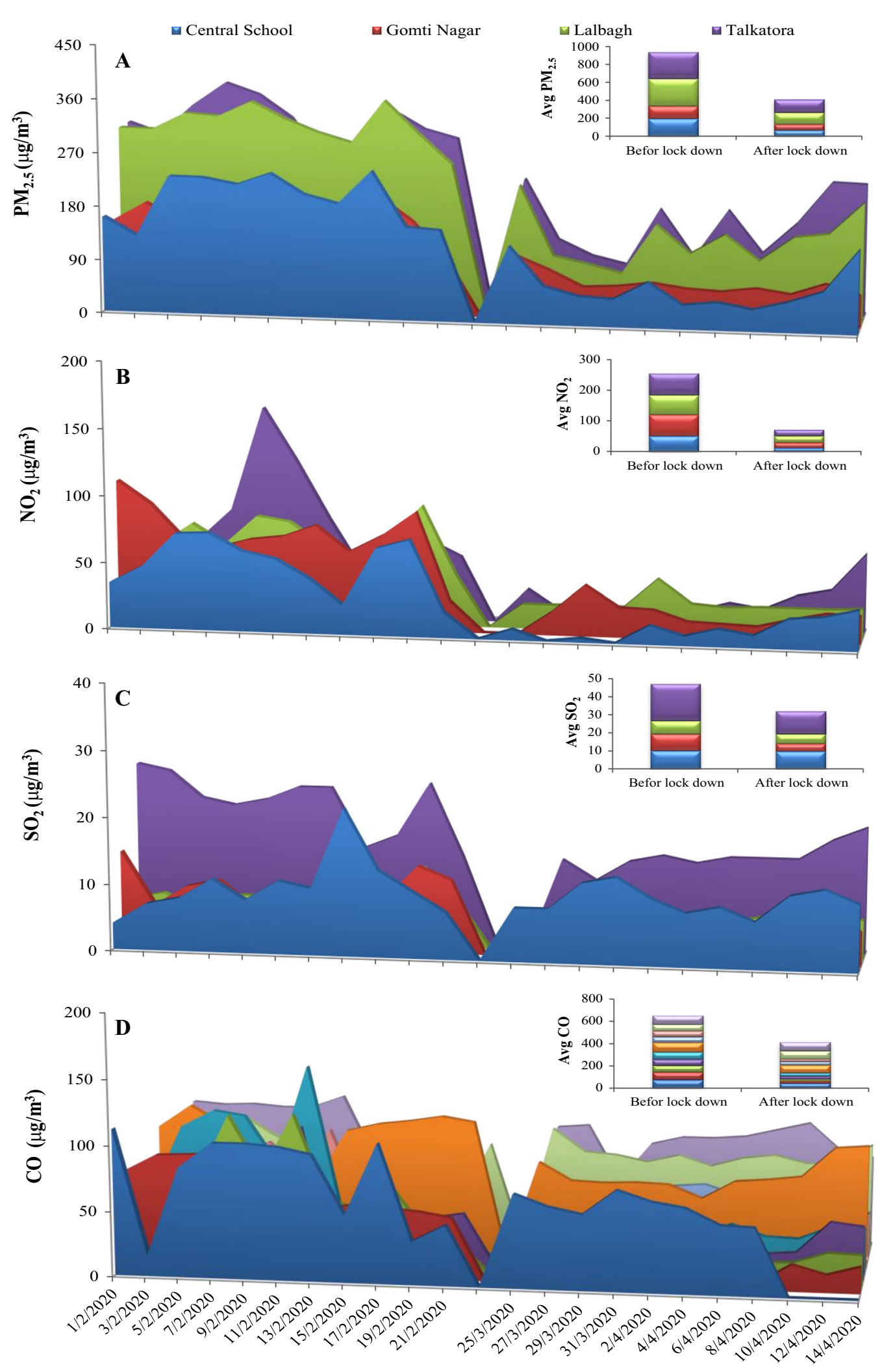

Before Lockdown

After Lockdown

Fig. 2 a-d The effects of lockdown before and after $\mathrm{PM}_{2.5}, \mathrm{NO}_{2}, \mathrm{SO}_{2}$ and $\mathrm{CO}$ level at Lucknow city 

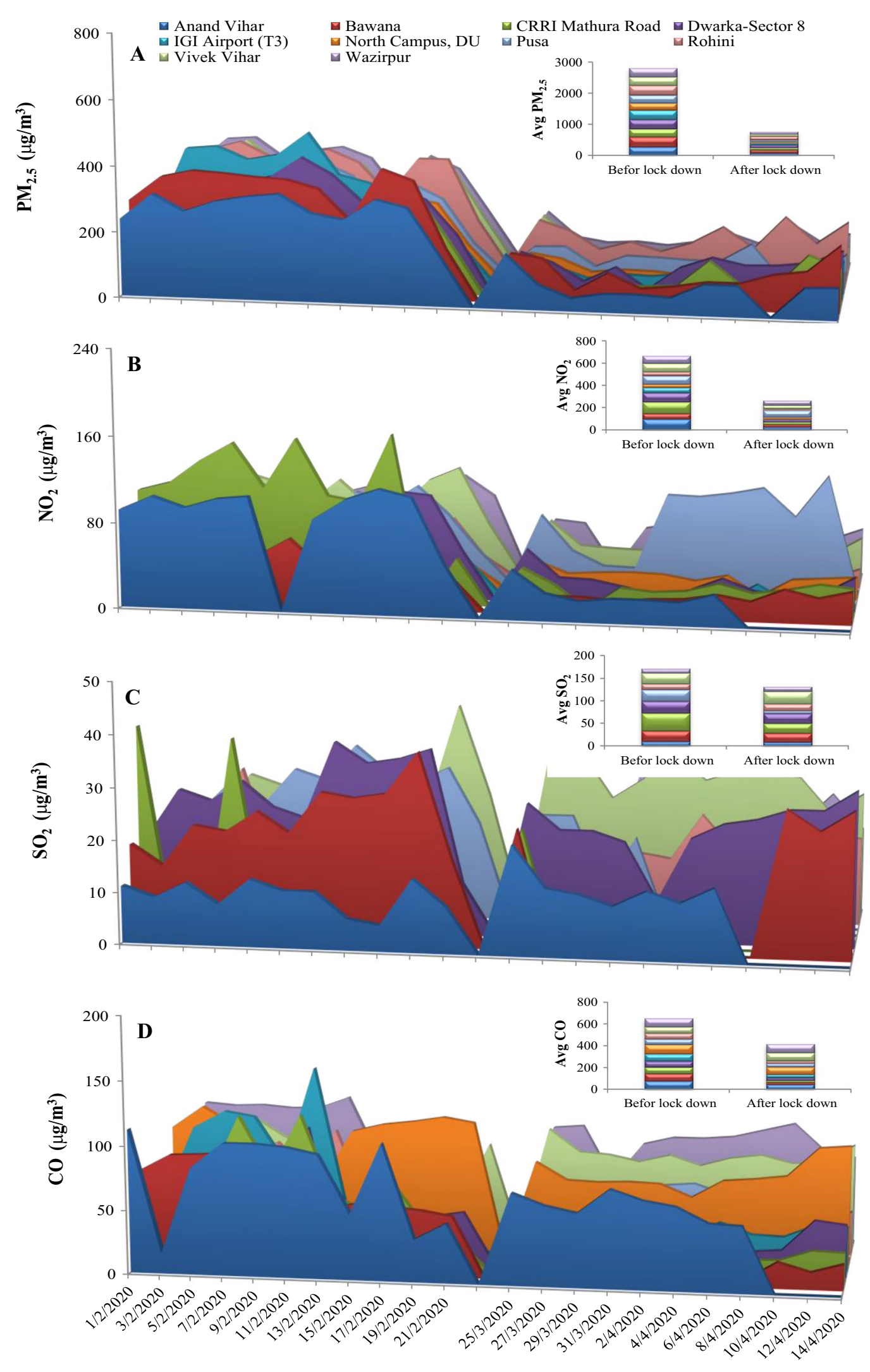

Before Lockdown

After Lockdown

Fig. 3 a-d The effects of lockdown before and after $\mathrm{PM}_{2.5}, \mathrm{NO}_{2}, \mathrm{SO}_{2}$ and $\mathrm{CO}$ level at Lucknow and Delhi city 
average value of $\mathrm{PM}_{2.5}$ was $140.54 \mu \mathrm{g} / \mathrm{m}^{3}$ (Gomti Nagar) and $65.09 \mu \mathrm{g} / \mathrm{m}^{3}$ (Gomti Nagar) before and after lockdown, respectively in Lucknow. For New Delhi, the minimum average values of $\mathrm{PM}_{2.5}$ were $225.63 \mu \mathrm{g} / \mathrm{m}^{3}$ (North Campus, DU) and $43.18 \mu \mathrm{g} / \mathrm{m}^{3}$ (North Campus, DU) before and after lockdown, respectively. In case of $\mathrm{NO}_{2}$ the average value was $50.90 \mu \mathrm{g} / \mathrm{m}^{3}$ (before) and $11.82 \mu \mathrm{g} / \mathrm{m}^{3}$ (after) in Central School, Lucknow and $28.0 \mu \mathrm{g} / \mathrm{m}^{3}$ (North Campus DU) and $4.36 \mu \mathrm{g} / \mathrm{m}^{3}$ (IGI Airport) in New Delhi before and after lockdown, respectively. The minimum average value of $\mathrm{SO}_{2}$ was found to be $7.18 \mu \mathrm{g} / \mathrm{m}^{3}$ (Central School) and $4.18 \mu \mathrm{g} / \mathrm{m}^{3}$ (Talkatora) in Lucknow before and after lockdown, respectively. The values of $\mathrm{SO}_{2}$ were $9.90 \mu \mathrm{g} / \mathrm{m}^{3}$ (Anand Vihar) and $6.0 \mu \mathrm{g} / \mathrm{m}^{3}$ (Pusa) in New Delhi before and after lockdown, respectively. In case of $\mathrm{CO}$, the minimum average value was $40.0 \mu \mathrm{g} / \mathrm{m}^{3}$ (Gomati Nagar) and $35 \mu \mathrm{g} / \mathrm{m}^{3}$ (Gomti Nagar) in Lucknow and $49.91 \mu \mathrm{g} / \mathrm{m}^{3}$ (Pusa) and $17.18 \mu \mathrm{g} / \mathrm{m}^{3}$ (Bawana) in New Delhi before and after lockdown, respectively. These 21 days average values of all four major air contaminants for before and after lockdown periods clearly indicate the significant reduction in the concentration of primary air pollutants.

Hence, the trend analysis depicted a decline in air pollution indices in both the cities. However, some areas, like residential colonies, airport terminals and official localities, where the cleanliness is maintained in much better way and vehicular load is less, the pollution was found to be low even during normal phase. Hence, the minimum levels do not clearly indicate the extent of decline in overall pollution across the city during lockdown phase. $\mathrm{PM}_{2.5}$ are submicron size particles, which affect health of people through congestion in lungs (Ma et al. 2017; Li et al. 2018). $\mathrm{NO}_{2}, \mathrm{SO}_{2}$ and $\mathrm{CO}$ affects human health severely and cause respiratory tract illness, asthma exacerbations and decreased lung function etc. (Harre et al. 1997; Oguntoke and Yussuf 2010). However, even after the decline, the level of $\mathrm{PM}_{2.5}$ remained higher than WHO recommended level of $10 \mu \mathrm{g} / \mathrm{m}^{3}$ for the annual mean (WHO 2006). Same is true for other parameters, whose WHO safe limits are $40 \mu \mathrm{g} / \mathrm{m}^{3}\left(\mathrm{NO}_{2}\right), 20 \mu \mathrm{g} /$ $\mathrm{m}^{3}\left(\mathrm{SO}_{2}\right)$ and $25 \mu \mathrm{g} / \mathrm{m}^{3}(\mathrm{CO})$ for the annual mean Nonetheless, such a significant decline in air quality is supposed to lead to improved health of people and avoid air pollution linked health problems and even deaths. He et al. (2020) in a similar study on lockdown induced air pollution effects in China indicated that improvement in air quality might avoid 24,000 to 36,000 premature deaths on a monthly basis. However, they suggested that if indoor air quality becomes toxic during lockdown, it might reduce the presumed benefits (He et al. 2020). The exact benefits of current air pollution decline would come to knowledge in due course of time. Presently, however, it is well clear that reduced human activities have created a much clear and clean air.

The AQI was also calculated for 14 locations for before and after lockdown in two cities (Fig. 4). The AQI of Lucknow was found to be in the range of 115.80 to 199.50 and remained in the unhealthy moderately polluted to poor range (AQI between 101 and 200) as described in the NAQI (Table S2). After the implication of lockdown, the AQI was significantly changed and was found to be in the range of 46.64 to 93.11 which falls in Good (0-50 at Central School
Fig. 4 Air Quality Index in Lucknow and Delhi city (Before and After Lockdown). AQI were calculated using $\mathrm{PM}_{2.5}$, $\mathrm{SO}_{2}$ and $\mathrm{NO}_{2}$

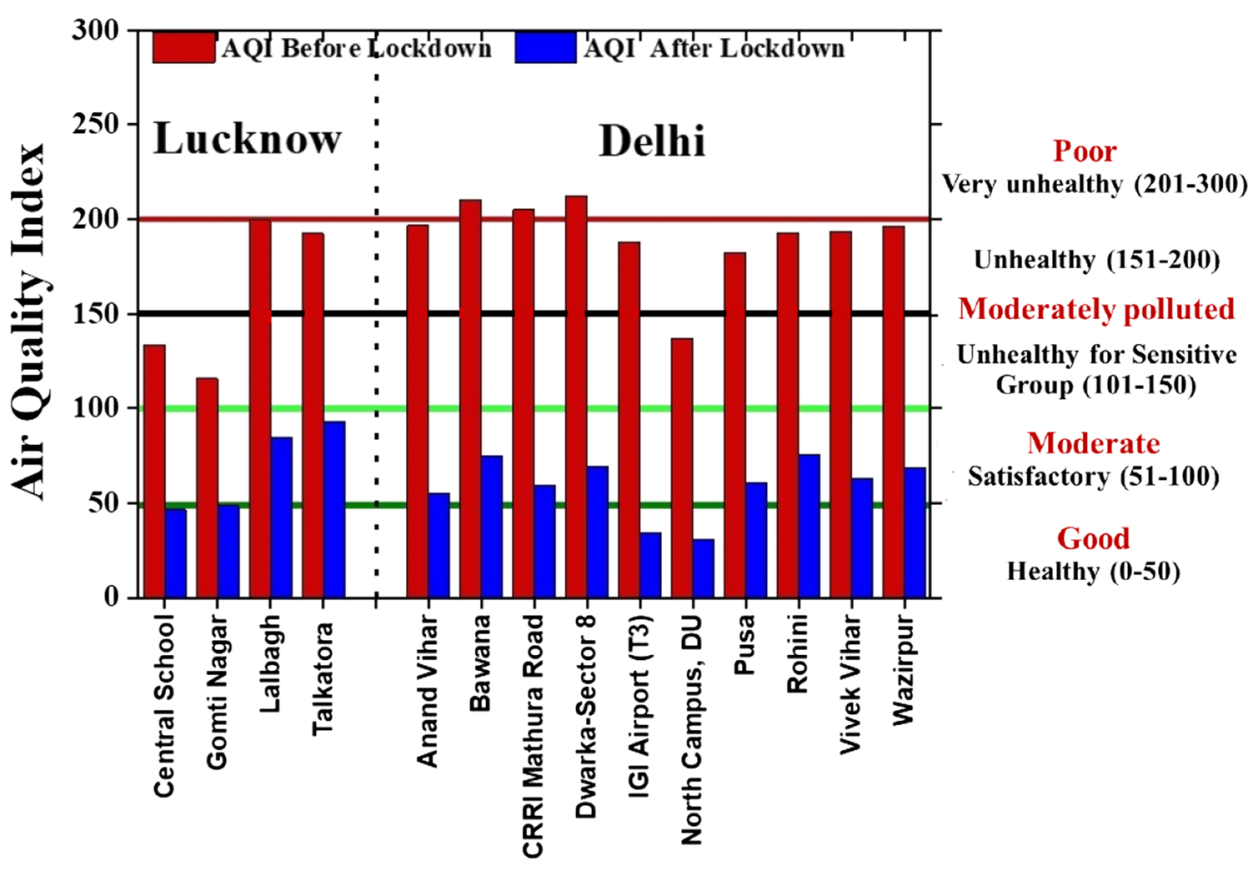

Locations 
Fig. 5 a, b Air mass back trajectory for Lucknow (a) and Delhi (b) The air trajectory before (solid line) and after lockdown (dotted line)
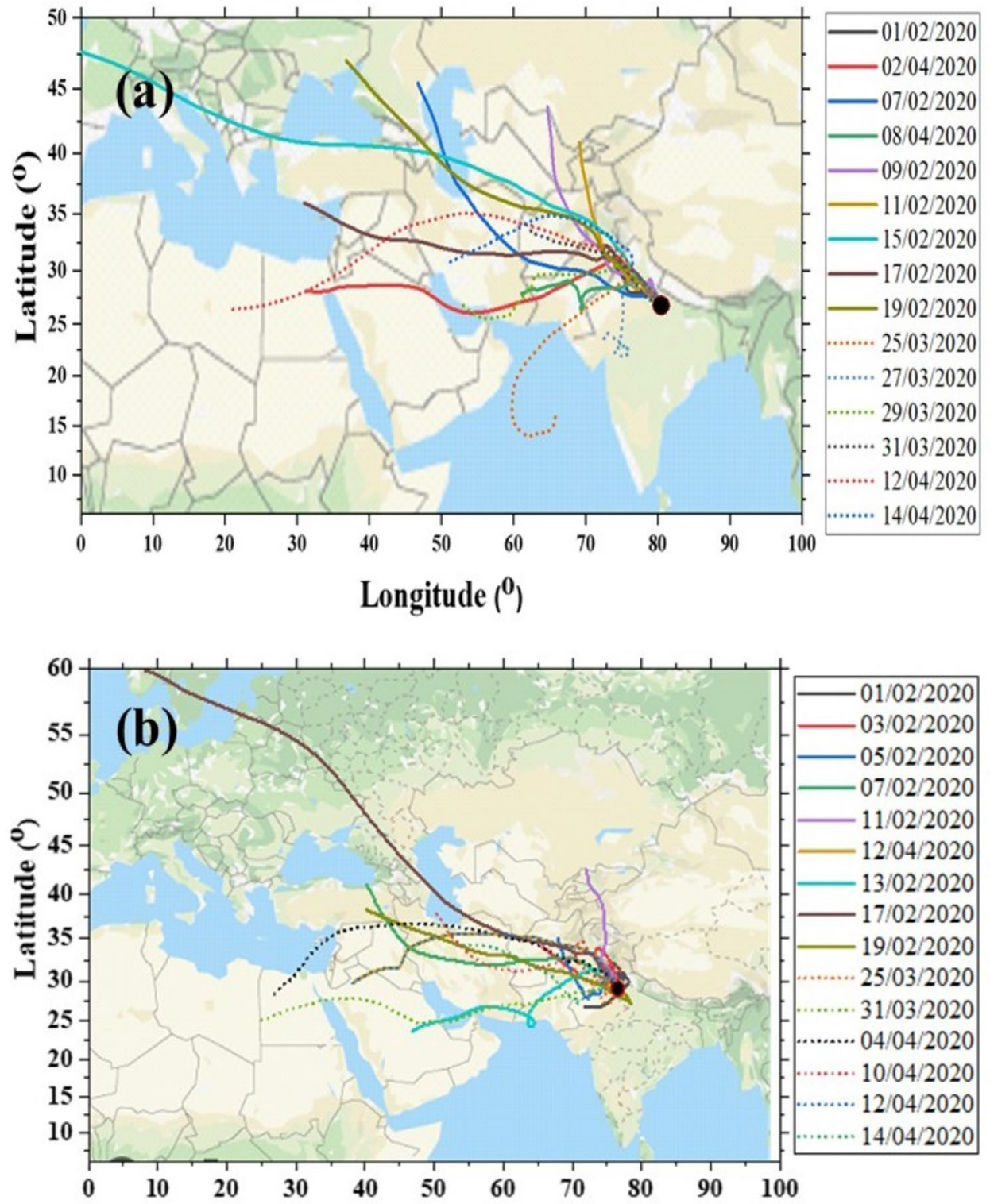

Longitude $\left({ }^{\circ}\right)$ and Gomti Nagar) to satisfactory (51-100 Lalbagh and Talkatora) AQI range.

In New Delhi, the AQI was found to be poor at Bawana, CRRI Mathura Road and Dwarka-sector 8, as well as at some other monitoring site such as Anand Vihar, IGI airport (T3), North Campus Delhi University (DU), Pusa, Rohini, VivekVihar and Wazipur with the values (137-210) being in moderately polluted to poor AQI range (101 to 200) before the implication of lockdown. However, a dramatic reduction was observed in the AQI at all ten monitoring sites over Delhi with AQI range of 31.07 to 75.50 after lockdown. Thus, AQI values after lockdown fell in the range of good to satisfactory. The drastic change observed AQI values were mainly due to cut down in local anthropogenic emission sources such as industrial units, vehicular movements, transportation, and construction work, etc.

To understand the influence of long-range transportation of atmospheric pollutants at both monitoring zones, the air mass back trajectory analysis was also performed. Air mass trajectories for four locations in Lucknow and ten locations in Delhi were very close to each other and so locations were considered as a single location in both cities. The mass concentration of $\mathrm{PM}_{2.5}, \mathrm{SO}_{2}, \mathrm{NO}_{2}$ and $\mathrm{CO}$ showed significant fluctuation during before lockdown and after lockdown periods (Fig. 5a, b). The air mass travelled from European, African, and Gulf countries as well Afghanistan, Tajikistan, Western Pakistan via Rajasthan, Punjab to Delhi and then to Lucknow during both events. However, few trajectories 
also originated from the Arabian Sea and the Gujrat state of India in case of Lucknow. In New Delhi, significant contribution was also noticed from local emission entities located in National Capital Region (NCR). So the air quality in both cities was dominantly influenced by long-range transportation, which also contributed to variation in the pollutant load. Air back mass trajectory has been well documented and examined by Tiwari et al. (2016) and Yerramsetti et al. (2013) for ambient air of Delhi and Lucknow, respectively.

In conclusion, results of the present study indicate a sharp decline in overall air quality indexes and in the concentration of primary air pollutants. The study needs to be extended to analysis of secondary air pollutants, such as ozone, also. However, such a lockdown cannot be planned in normal conditions in such a huge country and therefore it cannot be considered as a permanent solution. Nevertheless, taking lessons from the present lockdown and emerging and foreseen environmental scenarios, we propose following prospective measures that can be adopted in future to mitigate air pollution.

1. In every 3 to 6 months, a short 3 to 5 days complete/partial lockdown can be practiced to mitigate environmental pollution especially air pollution. During such a lockdown, people should be encouraged to have regular walk and jogging in nearby areas without vehicular use. In this way, people would not only avoid continuous indoor air and mental stress of lockdown but would also enjoy outside clean air.

2. Weekly or fortnightly, one "no vehicle day" can be practiced.

Acknowledgements Authors are thankful to Department of Botany, University of Lucknow. Amit Kumar is thankful to SERB, DST, New Delhi for the award and financial assistance in form of SERB-NPDF. KB acknowledges DST-Science and Engineering Research Board (SERB), New Delhi, India for financial support (EEQ/2017/000476). The authors are thankful to Central Pollution Control Board, New Delhi and Uttar Pradesh Pollution Control Board, Lucknow. The authors are thankful to Ministry of Environment Forest and Climate Change, New Delhi.

\section{Compliance with Ethical Standards}

Conflict of interest The authors declare that they have no conflict of interest.

\section{References}

Baig AM, Khaleeq A, Ali U, Syeda H (2020) Evidence of the COVID19 virus targeting the CNS: tissue distribution, host-virus interaction, and proposed neurotropic mechanisms. ACS Chem Neurosci 11:995
Banerjee AV, Duflo E, Glennerster R (2008) Putting a band-aid on a corpse: incentives for nurses in the Indian public health care system. J Eur Econ Assoc 6(2-3):487-500

Central Pollution Control Board, New Delhi, (2020) https://app. cpcbccr.com/AQI_India/; https://www.dpccairdata.com and https://air-quality.com. Accessed 15 April, 2020.

Chen H, Guo J, Wang C, Luo F, Yu X, Zhang W, Li J, Zhao D, Xu D, Gong Q, Liao J (2020) Clinical characteristics and intrauterine vertical transmission potential of COVID-19 infection in nine pregnant women: a retrospective review of medical records. The Lancet 395(10226):809-815

Deep A, Pandey CP, Nandan H, Purohit KD, Singh N, Singh J, Ojha N (2019) Evaluation of ambient air quality in Dehradun city during 2011-2014. J Earth Syst Sci 128(4):96

Driggin E, Madhavan MV, Bikdeli B, Chuich T, Laracy J, BondiZoccai G, Brown TS, Der Nigoghossian C, Zidar DA, Haythe J, Brodie D (2020) Cardiovascular considerations for patients, health care workers, and health systems during the coronavirus disease 2019 (COVID-19) pandemic. J Am Col Cardiol. https ://doi.org/10.1016/j.jacc.2020.03.031

Gautum S (2020) The influence of COVID-19 on air quality in India: a boon or inutile. Bull Environ Contam Toxicol. https://doi. org/10.1007/s00128-020-02877-y

Gu J, Han B, Wang J (2020) COVID-19: gastrointestinal manifestations and potential fecal-oral transmission. Gastroenterology 158:1518

Guo YR, Cao QD, Hong ZS, TanYY CSD, Jin HJ, Tan KS, Wang DY, Yan Y (2020) The origin, transmission and clinical therapies on coronavirus disease 2019 (COVID-19) outbreak-an update on the status. Mil Med Res 7(1):1-10

Guttikunda S (2010) Air quality index (AQI) for Delhi, India: trend analysis \& implications for the commonwealth games 2010 \& beyond. Sim-Air Working Paper Series, 35-2010.

Harre ES, Price PD, Ayrey RB, Toop LJ, Martin IR, Town GI (1997) Respiratory effects of air pollution in chronic obstructive pulmonary disease: a three month prospective study. Thorax 52(12):1040-1044

He G, Pan Y, Tanaka T (2020) COVID-19, city lockdown, and air pollution: evidence from China. medRxiv. https://doi. org/10.1101/2020.03.29.20046649

He Z, Kim YJ, Ogunjobi KO, Hong CS (2003) Characteristics of $\mathrm{PM}_{2.5}$ species and long-range transport of air masses at Taean background station South Korea. Atmos Environ 37(2):219-230

Joshi PC, Mahadev S (2011) Distribution of air pollutants in ambient air of district Haridwar (Uttarakhand), India: a case study after the establishment of State Industrial Development Corporation. Int J Environ Sci 2(1):237-258

Li R, Zhou R, Zhang J (2018) Function of PM2.5 in the pathogenesis of lung cancer and chronic airway inflammatory diseases. Oncollet 15(5):7506-7514

Ma JH, Song SH, Guo M, Zhou J, Liu F, Peng L, Fu ZR (2017) Long-term exposure to PM2.5 lowers influenza virus resistance via down-regulating pulmonary macrophage Kdm6a and mediates histones modification in IL- 6 and IFN- $\beta$ promoter regions. Biochem Biophys Res Commun 493(2):1122-1128

Ma S, Xiao Z, Zhang Y, Wang L, Shao M (2020) Assessment of meteorological impact and emergency plan for a heavy haze pollution episode in a Core City of North China Plain. Aerosol Air Qual Res 20:26-42

Mahato S, Pal S, Ghosh KG (2020) Effect of lockdown amid COVID19 pandemic on air quality of the megacity Delhi. India Sci Total Environ 730:139086

Ministry of Statistics and Programme Implementation, Govt. of India, New Delhi, (2020) https://statisticstimes.com/demographics/popul ation-of-india.php. Accessed 30 April, 2020. 
Nakada LYK, Urban RC (2020) COVID-19 pandemic: impacts on the air quality during the partial lockdown in São Paulo state. Brazil Sci Total Environ 730:139087

National Air Quality Index (2014), Central Pollution Control Board (Ministry of Environment, Forests \& Climate Change), New Delhi. https://www.indiaenvironmentportal.org.in/files/file/ Air\%2520Quality\%2520Index.pdf. Accessed 15 April, 2020.

Oguntoke O, Yussuf AS (2010) Air pollution arising from vehicular emissions and the associated human health problems in Abeokuta Metropolis Nigeria. ASSET 8(2):119-132

Punith YN, Nagarajappa DP (2017) Monitoring of SPM, $\mathrm{SO}_{2}, \mathrm{NO}_{2}$, and AIR quality index in selected areas of Davangere city during summer season. Glob Res Dev J Eng 2(11):10-18

Ramani KV, Mavalankar D (2006) Health system in India: opportunities and challenges for improvements. J Health Organ Manag 20:560

Rozwadowska A, Zieliński T, Petelski T, Sobolewski P (2010) Cluster analysis of the impact of air back-trajectories on aerosol optical properties at Hornsund Spitsbergen. Atmos Chem Phys 10:3

Shabudeen PS (2011) Impact upon the Indian socio-economic fronts by climate change. Ind J Sci Technol 4(3):192-196

Sharma S, Zhang M, Gao J, Zhang H, Kota SH (2020) Effect of restricted emissions during COVID-19 on air quality in India. Sci Total Environ 728:138878

Stein AF, Draxler RR, Rolph GD, Stunder BJB, Cohen MJ, Ngan F (2015) HYSPLIT atmospheric transport and dispersion modeling system. Bull Am Meteorol Soc 96(12):2059-2077

Tiwari S, Gautam AS, Dumka UC (2016) Assessment of PM 25 and PM 10 over Guwahati in Brahmaputra River Valley: temporal evolution, source apportionment and meteorological dependence, Atmospheric Pollut Res, 1-16.
Wang P, Chen K, Zhu S, Wang P, Zhang H (2020) Severe air pollution events not avoided by reduced anthropogenic activities during COVID-19 outbreak. Resour Conserv Recycl 158:104814

World Health Organization (WHO) (2006) WHO Air quality guidelines for particulate matter, ozone, nitrogen dioxide and sulfur dioxide: global update 2005: summary of risk assessment (No. WHO/SDE/ PHE/OEH/06.02), Geneva

World Health Organization (2020) Coronavirus disease (COVID-2019) situation reports. World Health Organization, Geneva.https:// www.who.int/emergencies/diseases/novel-coronavirus-2019. Accessed 14 May, 2020.

World Urbanization Prospects, (2020). Population Division, New York, USA.https://worldpopulationreview.com/world-cities/. Accessed 15 April, 2020.

Yerramsetti VS, Sharma AR, Navlur NG, Rapolu V, Dhulipala NC, Sinha PR (2013) The impact assessment of Diwali fireworks emissions on the air quality of a tropical urban site, Hyderabad, India, during three consecutive years. Environ Monit Assess 185(9):7309-7325

Zhu N, Zhang D, Wang W, Li X, Yang B, Song J, Zhao X, Huang B, Shi W, Lu R, Niu P (2020) A novel coronavirus from patients with pneumonia in China, 2019. N Engl J Med 382(8):727-733

Publisher's Note Springer Nature remains neutral with regard to jurisdictional claims in published maps and institutional affiliations. 